\title{
Phytoprotection
}

\section{Phytotoxicity of Fusarium, other fungal isolates, and of the phytotoxins fumonisin, fusaric acid, and moniliformin to jimsonweed}

\author{
H.K. Abbas, C.D. Boyette et R.E. Hoagland
}

Volume 76, numéro 1, 1995

URI : https://id.erudit.org/iderudit/706081ar

DOI : https://doi.org/10.7202/706081ar

Aller au sommaire du numéro

Éditeur(s)

Société de protection des plantes du Québec (SPPQ)l

ISSN

0031-9511 (imprimé)

1710-1603 (numérique)

Découvrir la revue

Citer cet article

Abbas, H., Boyette, C. \& Hoagland, R. (1995). Phytotoxicity of Fusarium, other fungal isolates, and of the phytotoxins fumonisin, fusaric acid, and moniliformin to jimsonweed. Phytoprotection, 76(1), 17-25.

https://doi.org/10.7202/706081ar
Résumé de l'article

Dix isolats fongiques isolés de la stramoine commune (Datura stramonium) et 7 isolats provenant d'espèces cultivées ont été examinés pour la production de phytotoxines et pour leur pouvoir pathogène sur des plantules de stramoine commune cultivées en serre. Quatre isolats de Fusarium moniliforme, trois isolatsde $F$. semitectum, un isolatde $F$. oxysporum, un isolatde Cephalosporium spp. et un isolât d'Alternaria crassa prélevés sur des plantules de stramoine commune infectées, et sept isolats supplémentaires de $F$. moniliforme obtenus de grains et de plantules d'espèces cultivées ont été mis en culture sur du riz (Oryza sativa) autoclave. Les mélanges champignon-riz ont été moulus et leur phytotoxicite sur des plantules de stramoine commune âgées de 1 et 2 semaines a été testée par des applications foliaires. Tous les extraits de riz infestés par un champignon ( 5 g de mélange riz-champignon $50 \mathrm{ml}^{-1}$ d'eau) ont causé des dommages ou la mort des plantules, sauf les extraits d'isolats de $F$. semitectum, Cephalosporium spp. et $A$. crassa. Les mélanges champignon-riz ont été analysés de façon quantitative pour la présence de phytotoxines du fusarium[fumosinine $\mathrm{B}_{1}\left(\mathrm{FB}_{1}\right)$, acide fusarique et moniliformine]. Aucun isolât n'a produit plus d'une de ces phytotoxines dans les extraits de champignon-riz. La FB était produite par tous les isolats de $F$. moniliforme isolés selon une échelle de concentration de $\leqslant 5$ à $850 \mu \mathrm{g} \mathrm{mL}^{-1}$ de mélange champignon-riz. L'isolât de $F$. oxysporum a produit $3,5 \mathrm{~g} \mathrm{~m} \mathrm{~L}^{-1}$ de moniliformine et aucune phytotoxine n'a été détectée dans les extraits de F. semitectum, Cephalosporium spp. ou A. crassa. La fumonisine, l'acide fusarique et la moniliformine appliqués à l'état pur à du feuillage de stramoine commune à 6-50,25-800 et 50-800 $\mu \mathrm{g} \mathrm{mL}^{-1}$ ont causé des symptômes similaires à ceux des isolats fongiques qui avaient produit ces composés. Des tests sur le pouvoir pathogène des spores de tous les isolats sur la stramoine ont indiqué que les isolats étaient avirulents, sauf $A$. crassa qui a causé des infections seulement après une durée d'humectation $\geqslant 12 \mathrm{~h}$
Ce document est protégé par la loi sur le droit d'auteur. L’utilisation des services d’Érudit (y compris la reproduction) est assujettie à sa politique d'utilisation que vous pouvez consulter en ligne.

https://apropos.erudit.org/fr/usagers/politique-dutilisation/ 


\title{
Phytotoxicity of Fusarium, other fungal isolates, and of the phytotoxins fumonisin, fusaric acid, and moniliformin to jimsonweed
}

\author{
Hamed K. Abbas, C. Douglas Boyette, and Robert E. Hoagland ${ }^{1}$
}

Received 1994-04-14; accepted 1995-06-20

Ten fungal isolates from jimsonweed (Datura stramonium L.) and 7 from crop species were examined for phytotoxin production and pathogenicity on jimsonweed seedlings in the greenhouse. Four isolates of Fusarium moniliforme, three F. semitectum isolates, a $F$. oxysporum isolate, a Cephalosporium spp. isolate, and an Alternaria crassa isolate from diseased jimsonweed seedlings, plus seven additional $F$. moniliforme isolates from seeds and seedlings of crop species were grown on autoclaved rice (Oryza sativa). The fungus-rice mixtures were ground and tested for phytotoxicity on 1- and 2-wk-old jimsonweed seedlings via foliar application. All fungus-infested rice extracts $(5 \mathrm{~g}$ fungus-rice mixture $50 \mathrm{~mL}^{-1}$ water) caused injury or mortality to the seedlings except the extracts from isolates of $F$. semitectum, Cephalosporium spp., and $A$. crassa. Fungus-rice mixtures were quantitatively analyzed for the presence of Fusarium phytotoxins [fumonisin $B_{1}\left(F B_{1}\right)$, fusaric acid, and moniliformin]. No isolate produced more than one of these phytotoxins in the fungus-rice extract. FB was produced by all $F$. moniliforme isolates in a concentration range of $\leq 5$ to $850 \mu \mathrm{g} \mathrm{mL} \mathrm{m}^{-1}$ of fungus-rice extract. The $F$. oxysporum isolate produced moniliformin at $3.5 \mathrm{~g} \mathrm{~mL}^{-1}$, and no phytotoxins were detected in extracts of F. semitectum, Cephalosporium spp., or A. crassa. Pure fumonisin, fusaric acid, and moniliformin applied to jimsonweed foliage at 6-50, 25-800, and $50-800 \mu \mathrm{g} \mathrm{mL}-1$, respectively, caused symptoms similar to that of the fungal isolates that produced these compounds. Pathogenicity tests of spores of all isolates on jimsonweed indicated that the isolates were avirulent, except for $A$. crassa which infected only after a dew period $\geq 12 \mathrm{~h}$.

Abbas, H.K., C.D. Boyette et R.E. Hoagland. 1995. Phytotoxicité du Fusarium et d'autres isolats fongiques, ainsi que des phytotoxines fumonisine, acide fusarique et moniliformine envers la stramoine commune. PHYTOPROTECTION 76: 17-25.

Dix isolats fongiques isolés de la stramoine commune (Datura stramonium) et 7 isolats provenant d'espèces cultivées ont été examinés pour la production de phytotoxines et pour leur pouvoir pathogène sur des plantules de stramoine commune cultivées en serre. Quatre isolats de Fusarium moniliforme, trois isolats de F. semitectum, un isolat de F. oxysporum, un isolat de Cephalosporium spp. et un isolat d'Alternaria crassa prélevés sur des plantules de stramoine commune infectées, et sept isolats supplémentaires de F. moniliforme obtenus de grains et de plantules d'espèces cultivées ont été mis en culture sur du riz (Oryza sativa) autoclavé. Les mélanges champignon-riz ont été moulus et leur

1. USDA-ARS, Southern Weed Science Laboratory, P.O. Box 350, Stoneville, Mississippi, U.S.A. 38776 
phytotoxicité sur des plantules de stramoine commune âgées de 1 et 2 semaines a été testée par des applications foliaires. Tous les extraits de riz infestés par un champignon ( $5 \mathrm{~g}$ de mélange riz-charnpignon $50 \mathrm{~mL}^{-1} \mathrm{~d}^{\prime}$ eau) ont causé des dommages ou la mort des plantules, sauf les extraits d'isolats de $F$. semitectum, Cephalosporium spp. et $A$. crassa. Les mélanges champignon-riz ont été analysés de façon quantitative pour la présence de phytotoxines du Fusarium [fumosinine $B_{1}\left(F B_{1}\right)$, acide fusarique et moniliformine]. Aucun isolat n'a produit plus d'une de ces phytotoxines dans les extraits de champignon-riz. La FB était produite par tous les isolats de $F$. moniliforme isolés selon une échelle de concentration de $\leq 5$ à $850 \mu \mathrm{g} \mathrm{mL}^{-1}$ de mélange champignon-riz. L'isolat de $F$. oxysporum a produit $3,5 \mathrm{~g} \mathrm{~mL}^{-1}$ de moniliformine et aucune phytotoxine $\mathrm{n}^{\prime}$ a été détectée dans les extraits de F. semitectum, Cephalosporium spp. ou A. crassa. La fumonisine, I'acide fusarique et la moniliformine appliqués à l'état pur à du feuillage de stramoine commune à 6-50, 25-800 et 50-800 $\mathrm{g} \mathrm{g} \mathrm{mL}^{-1}$ ont causé des symptômes similaires à ceux des isolats fongiques qui avaient produit ces composés. Des tests sur le pouvoir pathogène des spores de tous les isolats sur la stramoine ont indiqué que les isolats étaient avirulents, sauf $A$. crassa qui a causé des infections seulement après une durée d'humectation $\geq 12 \mathrm{~h}$.

\section{INTRODUCTION}

There is currently much interest in the use of various microbes and microbial products as weed control agents (Hoagland 1990a; TeBeest 1991). A current project in our laboratory involves the control of jimsonweed (Datura stramonium L.) utilizing various fungi, including several Fusarium species. Phytotoxicity of Fusarium species and their secondary metabolites have been well documented on field crops (Abbas et al. 1992; Burmeister and Plattner 1987; Datnoff and Sinclair 1988; Nelson 1992; Stack and McMullen 1985; Van Asch et al. 1992), fruits (Labuschagne et al. 1987; Timer 1982), and vegetables (Jones and Woltz 1981; Kuo and Scheffer 1964; Mirocha et al. 1992). Little has been reported on the phytotoxicity of Fusarium species and their secondary metabolites on weeds. One report (Abbas et al. 1991) showed that $F$. moniliforme (Sheldon) isolated from jimsonweed caused profound damage to jimsonweed and some other weed species. That isolate produced fumonisin $\mathrm{B}_{1}\left(F \mathrm{~B}_{1}\right)$ in copious amounts and some related fumonisin compounds as minor metabolites (Abbas et al. 1992). FB was also shown to be responsible for the fungal phytotoxicity to jimsonweed and other weeds (Abbas and Boyette 1992; Abbas et al. 1991; Duke et al. 1991; Tanaka et al. 1993). Fusarium species are well known for their production of phytotoxins such as fumonisins (Abbas et al. 1992; Gelderblom et al. 1988; Vesonder et al. 1990), fusaric acid (Abbas etal. 1989; Nelson etal. 1983), moniliformin (Abbas and Mirocha 1985; Nelson et al. 1983), enniatin (Burmeister and Plattner 1987), and trichothecenes (Abbas et al. 1989; Matsuo 1982).

Earlier tests with several F. moniliforme isolates from diseased jimsonweed indicated a lack of pathogenicity (Abbas et al. 1992). The present study was initiated to further study and compare the pathogenicity and phytotoxicity of various isolates of Fusarium, Cephalosporium, and Alternaria crassa (Sacc.) Rands from jimsonweed, and Fusarium from several crop species, when grown on solid or liquid media. We also sought to quantitate $\mathrm{FB}_{1}$, fusaric acid, and moniliformin in fungus-rice (Oryza sativa L.) extracts of these fungi and to compare effects of fungal-rice extracts with those of highpurity forms of these three water-soluble toxins. Although $\mathrm{FB}_{1}$ is produced mainly by Fusarium spp., this mycotoxin was recently reported to be produced in other fungal genera such as Alternaria alternata (Fries) Kiesler f. sp. lycopersici (Chen et al. 1992). A. crassa was originally isolated from jimsonweed and shown to be pathogenic to this weed (Boyette 1986), but its pathogenicity and phytotoxin production 
had not been examined when cultured on solid media (rice grains) and when applied without dew. Because many of these organisms were isolated from diseased jimsonweed, an economically important weed in widespread areas of the world in soybean [Glycine max (L.) Merr.] and other crops (Mitich 1989), we used this weed as a bioassay species.

\section{MATERIALS AND METHODS}

\section{Plant material}

Jimsonweed seeds were mechanically scarified with sandpaper and planted in the greenhouse in a commercial potting mixture supplemented with a slow release N-P-K fertilizer(14-14-14). The plants were watered as needed, and the temperature maintained between 28 and $32^{\circ} \mathrm{C}$ at $40-60 \% \mathrm{RH}$. The photoperiod was ca $14 \mathrm{~h}$ at $1600-1800 \mu \mathrm{mol} \mathrm{m}{ }^{-2} \mathrm{~s}^{-1}$ (PAR) at midday. Treatments were applied when plants were 1- and 2-wk-old (2- to 4-leaf stage).

\section{Fungal isolation}

Fungal isolates and sources used in these studies are listed in Table 1. Isolates of Fusarium spp. (JW\#1 and JW\#3 to JW\#9) and Cephalosporium spp. (JW\#2) were obtained from stems and seed coats of infected jimsonweed plants grown in the greenhouse using procedures described by Abbas et al. (1989, 1991). The five $F$. moniliforme cultures, M-521, M-728,
$\mathrm{M}-1271, \mathrm{M}-5519$ and $\mathrm{M}-5542$ were isolated from Kentucky bluegrass (Poa pratensis L.), Gladiolus spp., rice, and corn, respectively. F. moniliforme M-5542B arose in our laboratory as a sector (morphological variant) from $F$. moniliforme $\mathrm{M}-5542$. A. crassa was isolated from jimsonweed plants. F. moniliforme NRRL 18226 was isolated from corn (Zea mays L.) (Vesonder et al. 1990). Stock cultures of these fungi were maintained on an autoclaved skim milk-silica gel medium (Windels et al. 1988) stored at $-4^{\circ} \mathrm{C}$ in the laboratory.

\section{Inoculum production}

The inoculum for pathogenicity studies was produced by growing the isolates on neutral-dox yeast solution (Lukens 1960) to facilitate spore production. Fungal mats and spores were separated from the liquid culture by filtration. These fungal propagules were washed with distilled water, refiltered, and homogenized with distilled water in an electric blender. These inocula preparations contained fungal spores, mainly macroconidia, at concentrations between $3 \times 10^{6}$ and $7.8 \times 10^{7}$ spores $\mathrm{mL}^{-1}$, depending on the isolate. Spore concentrations were determined using a hemacytometer. These homogenized preparations were used directly as inocula.

The inoculum for phytotoxin analysis and phytotoxicity testing was produced by growing the isolates on a solid medium

Table 1. Sources of fungal isolates used

\begin{tabular}{lclll}
\hline Fungal isolate & $\begin{array}{c}\text { No. of } \\
\text { isolates }\end{array}$ & Code & Source & Origin \\
\hline Alternaria crassa $^{\mathrm{a}}$ & 1 & $\mathrm{NRRL}-18136$ & Jimsonweed & Mississippi \\
Cephalosporium spp. $^{\text {Fusarium moniliforme }}$ & 1 & JW $\# 2$ & Jimsonweed & Mississippi \\
Fusarium moniliforme $^{\mathrm{b}}$ & 1 & $\mathrm{M}-521$ & Kentucky bluegrass & Pennsylvania \\
Fusarium moniliforme $^{\mathrm{b}}$ & 1 & $\mathrm{M}-728$ & Gladiolus corms & Pennsylvania \\
Fusarium moniliforme $^{\mathrm{b}}$ & 1 & $\mathrm{M}-1271$ & Rice seed & Pennsylvania \\
Fusarium moniliforme $_{\text {Fusarium moniliforme }}$ & 2 & $\mathrm{M}-5519, \mathrm{M}-5542$ & Corn seed & Pennsylvania \\
Fusarium moniliforme & 1 & $\mathrm{M}-5542 \mathrm{~B}$ & Sector of M-5542 & Mississippi \\
Fusarium oxysporum & 1 & $\mathrm{NRRL}-\mathrm{A} 28160$ & Corn seed & Illinois \\
Fusarium semitectum & 4 & $\mathrm{JW} \# 1,4,5,9$ & Jimsonweed & Mississippi \\
\hline
\end{tabular}

a Fungus isolated from jimsonweed by Boyette (1986).

b Cultures purchased from the Fusarium Research Center Culture Collection, University Park, Pennsylvania. 
consisting of converted long-grain enriched rice (Uncle Ben's Inc., Houston, Texas) as described by Abbas et al. (1991, 1992). Rice grains $(200 \mathrm{~g})$ plus $140 \mathrm{~mL}$ distilled water were autoclaved in flasks for $1 \mathrm{~h}$ $\left(121^{\circ} \mathrm{C}, 15 \mathrm{psi}\right)$ on two consecutive days, resulting in sterile, hydrated rice grains with a moisture content of 35-37 \% (wt:wt). Individual flasks were inoculated with a given fungus and incubated at $22^{\circ} \mathrm{C}$ for $2 \mathrm{wk}$. The fungus-infested rice mixture was air-dried and ground into a powder. The powder $(5 \mathrm{~g})$ was added to $50 \mathrm{~mL}$ water for foliar spray application.

\section{Pathogenicity tests}

Fungal inocula from liquid culture were applied to leaves and stems of 1- and 2-wk-old (2- to 4-leaf stage) jimsonweed plants by spraying with an atomizer until runoff occurred. Control plants received distilled water. Plants were placed in a dew chamber for up to $24 \mathrm{~h}$, then transferred to the greenhouse for assessment of infection over a 10-d period. Three replicates were used for each treatment. Each replicate contained 12 jimsonweed plants. The experiment was repeated twice.

Inocula from solid culture fungus-rice extracts, prepared as described above, were applied to leaves and stems of jimsonweed seedlings by spraying to runoff with an atomizer. Control plants received filtrates of autoclaved rice. Plants were placed in the greenhouse immediately after treatment. Treated and control plants were observed daily and symptoms were evaluated using a visual injury rating scale described below. The height of 6 jimsonweed plants was recorded at the beginning and end ( $2 \mathrm{wk}$ ) of each experiment. Three replicates, each containing 12 jimsonweed plants, were used for each treatment, and the experiment was repeated twice. Analogous experiments were carried out in which fungal-rice extracts were applied to jimsonweed plants, which were then placed in a dew chamber for $10-20 \mathrm{~h}$ before being placed in the greenhouse for $2 \mathrm{wk}$.

\section{Injury or mortality determination}

Injury to and mortality of jimsonweed seedlings byliquid-culture inocula, fungalrice extracts, or purified phytotoxins was visually assessed $2 \mathrm{wk}$ after treatment, using a scale based on that described by Hoagland and Boyette (1994). Injury was assigned a value of $0-4$, where $0:=$ no injury $(0 \%)$ and $4=$ severe chlorosis, necrosis, growth inhibition, wilt, or mortality (100\%). Ratings were combined averages of rating values for two observations of three replicates (composed of 6-10 seedlings) of each treatment. Percent mortality was determined $2 \mathrm{wk}$ after treatment by direct counts of collapsed seedlings. Values of the replicates of each treatment were combined and averaged.

\section{Phytotoxin standards}

Standard samples of $\mathrm{FB}_{1}$ were isolated and purified in our laboratories using high performance liquid chromatography (HPLC) and fast atom bombardment rnass spectrometry (FAB-MS) methods described by Abbas et al. (1991, 1992) and Vesonder et al. (1990). Fusaric acid was purchased from Sigma Chemical Co. and moniliformin was provided by Dr. R. F. Vesonder.

\section{Phytotoxicity of pure phytotoxins}

To check the biological activity of the phytotoxins (FB, fusaric acid and moniliformin), intact plants were used as described in the section on pathogenicity tests. Various concentrations $(6.3-50 \mu \mathrm{g}$ $\mathrm{mL}^{-1}$ for $\mathrm{FB}_{1}$ and $6.3-800 \mu \mathrm{g} \mathrm{mL}^{-1}$ for moniliformin and fusaric acid) were sprayed until runoff. Treated plants were then placed in the greenhouse. Dry weights of plant shoot material (biomass) were determined at the end of the experiment after excising stems at the soil line and drying for $48 \mathrm{~h}$ at $60-70^{\circ} \mathrm{C}$.

\section{Phytotoxin extraction and quantification}

Procedures used for extraction, detection and determination of fusaric acid and moniliformin were described previously in Abbas et al. (1989). FB was extracted from fungus-infested rice as described in Abbas et al. (1991, 1992) and purified as described in Vesonder et al. (1990). The fungus-infested rice $(50 \mathrm{~g})$ was extracted with $300 \mathrm{~mL} 60 \%$ aqueous methanol and the extract purified by XAD-2, silica gel column chromatography and semipreparative HPLC on $\mathrm{C}-18$ reverse phase 
silica (Vesonder et al. 1990). FB, was obtained as a white powder. Authenticity was confirmed by comparison with a standard of $\mathrm{FB}_{1}$ from corn cultured with F. moniliforme MRS 825 (Gelderblom et al. 1988), using HPLC and FAB-MS techniques (Abbas et al. 1991, 1992; Vesonder et al. 1990).

\section{RESULTS}

Pathogenicity tests of the 17 liquid culture inocula followed by dew periods up to $24 \mathrm{~h}$ indicated that only $A$. crassa infected the young jimsonweed plants. The infectivity of $A$. crassa was expected, given its documented pathogenicity on this weed host (Boyette 1986). In the present tests, A. crassa from liquid culture $\left(6.2 \times 10^{6}\right.$ spores $\left.\mathrm{mL}^{-1}\right)$ caused $100 \%$ injury and high mortality ( $\geq 95 \%$ ) to 1 - and 2-wk-old jimsonweed seedlings 2 wk after treatment. These tests were not designed to show possible interactions of phytotoxins with pathogenic effects of the fungal-rice extracts. However, in those cases where no phytotoxic injury was apparent (lack of phytotoxin production and infectivity), we were able to assess pathogenicity when fungal-rice extracts were applied to jimsonweed plants with or without a dew period. Fungal-rice extracts of three $F$. semitectum Berk. \& Ravenel (JW \#6, \#7, and \#8), the Cephalosporium spp., and the $A$. crassa isolate produced no injury and thus exhibited no pathogenicity without a dew period. Only one of these isolates, $A$. crassa, exhibited pathogenicity when a dew period of $>10 \mathrm{~h}$ was supplied. Ratings were $100 \%$ injury and $85-95 \%$ mortality on the young jimsonweed plants 2 wk after treatment.

Fungus-rice extracts were examined for phytotoxicity and for levels of $\mathrm{FB}_{1}$, fusaric acid, and moniliformin. All F. moniliforme isolates produced $\mathrm{FB}_{1}$ in a range of $\leq 5$ to $850 \mu \mathrm{g} \mathrm{mL}^{-1}$ of fungus-rice extract (Table 2), but the other two phytotoxins were not detected. F. oxysporum (Schlect.) Synd. and Hans. from jimsonweed (JW \#3) produced moniliformin as a major phytotoxin $\left(3.5 \mathrm{~g} \mathrm{~mL}^{-1}\right)$, but did not produce $\mathrm{FB}_{1}$ or fusaric acid. Rice extracts of the three $F$. semitectum isolates (JW \#6, \#7, and \#8), one Cephalosporium spp. isolate from jimsonweed, and $A$. crassa contained noFB ${ }_{1}$ fusaric acid, or moniliformin.

Table 2. Effects on growth of jimsonweed plants and phytotoxin production of Fusarium spp. isolates grown on a rice medium ${ }^{\text {a }}$

\begin{tabular}{|c|c|c|c|c|c|}
\hline \multirow[b]{2}{*}{ Fungal isolate } & \multicolumn{2}{|c|}{ 1-wk-old plants } & \multicolumn{2}{|c|}{ 2-wk-old plants } & \multirow[b]{2}{*}{$\begin{array}{c}\mathrm{FB}_{1} \\
\left(\mu \mathrm{g} \mathrm{mL}^{-1}\right)\end{array}$} \\
\hline & $\begin{array}{c}\text { Injury } \\
(\%)\end{array}$ & $\begin{array}{c}\text { Mortality } \\
\langle \%\rangle\end{array}$ & $\begin{array}{c}\text { Injury } \\
(\%)\end{array}$ & $\begin{array}{c}\text { Mortality } \\
(\%)\end{array}$ & \\
\hline \multicolumn{6}{|l|}{ Controls } \\
\hline Distilled water & 0 & 0 & 0 & 0 & - \\
\hline Autoclaved rice extract & 0 & 0 & 0 & 0 & - \\
\hline \multicolumn{6}{|l|}{ F. moniliforme } \\
\hline JW \#1 & 100 & 100 & 100 & $89 \pm 21.3$ & 850 \\
\hline JW \#4 & 100 & 100 & 100 & $33 \pm 9.5$ & 420 \\
\hline JW \#5 & 100 & $95 \pm 19.3$ & 100 & $11 \pm 4.5$ & 340 \\
\hline JW \#9 & 100 & $90 \pm 17.2$ & 100 & $19 \pm 3.7$ & 315 \\
\hline M-521 & 100 & 0 & 100 & $6 \pm 2.2$ & $\leq 5$ \\
\hline $\mathrm{M}-728$ & 100 & 0 & $90 \pm 13.5$ & 0 & $\leq 5$ \\
\hline $\mathrm{M}-1271$ & $25 \pm 6.3$ & 0 & $20 \pm 9.5$ & 0 & $\leq 5$ \\
\hline$M-5519$ & 100 & 0 & $80 \pm 13.4$ & 0 & $\leq 5$ \\
\hline$M-5542$ & 100 & 0 & $85 \pm 11.2$ & 0 & $\leq 5$ \\
\hline M-5542B & 100 & $95 \pm 15.7$ & 100 & $17 \pm 5.2$ & 345 \\
\hline NRRL-A28160 & 100 & $10 \pm 5.2$ & 100 & 0 & $\leq 5$ \\
\hline \multicolumn{6}{|l|}{ F. oxysporum } \\
\hline JW \#3 & $80 \pm 17.5$ & 0 & 100 & 0 & 0 \\
\hline
\end{tabular}

${ }^{a} A$. crassa, Cephalosporium spp. and $F$. semitectum produced no injury symptoms or detectable levels of $\mathrm{FB}_{1}$, fusaric acid, or moniliformin. Results are the mean of three replicates for each treatment \pm one standard error. 
Assessment of the effect of these fungalrice extracts on jimsonweed seedlings showed a strong positive relationship between injury or mortality and the levels of phytotoxin produced (Table 2). Isolates could generally be grouped into several categories based on the extent of injury or mortality they exhibited. Isolate JW \#1 caused the highest injury and mortality to 1- and 2-wk-old jimsonweed seedlings, and it also produced the highest level of $\mathrm{FB}_{1}\left(850 \mu \mathrm{g} \mathrm{mL}^{-1}\right)$. Isolates $\mathrm{M}-5542 \mathrm{~B}, \mathrm{JW}$ \#9, JW \#5, and JW \#4 caused less injury and mortality and produced less $\mathrm{FB}_{1}$ $\left(345-420 \mu \mathrm{g} \mathrm{mL}^{-1}\right)$. A third group was comprised of isolates M-521, M-728, $\mathrm{M}-5519$, and $\mathrm{M}-5542$, and NRRL-A-28160, which caused high injury but no mortality; these fungi produced $\mathrm{FB}_{1}$ at $\leq 5 \mu \mathrm{g}$ $\mathrm{mL}^{-1}$. Isolate $\mathrm{M}-1271$ produced the lowest levels of $\mathrm{FB}_{1}$, and caused the lowest injury and no mortality. Fungal-rice extracts from the three $F$. semitectum isolates
(JW \#6, \#7 and \#8), the Cephalosporium spp. isolate (JW\#2), and $A$. crassa (NRRL18136), all lacking production of $\mathrm{FB}_{1}$, fusaric acid, or moniliformin, did not cause injury to jimsonweed.

High-purity $\mathrm{FB}_{1}$, fusaric acid, and moniliformin were applied to jimsonweed seedlings, and effects on plant growth, injury, and mortality determined (Table 3). Pure $\mathrm{FB}_{1}$ at 6.3, 12.5, 25, and $50 \mu \mathrm{g} \mathrm{mL}^{-1}$ was highly phytotoxic to jimsonweed plants. The symptoms caused by this phytotoxin were similar to those caused by the fungus-rice extracts of isolates that produced $\mathrm{FB}_{1}$. Pure moniliformin applied at $50-800 \mu \mathrm{g} \mathrm{mL}^{-1}$ caused symptoms similar to the fungusrice extract from JW \#3 (Table 3). None of the fungal isolates produced detectable levels of fusaric acid when grown on rice (Table 2). Nevertheless, this compound was more phytotoxic than moniliformin.

Table 3. Effects of various rates of application of three phytotoxins on the growth and biomass production of 2-wk-old jimsonweed plants ${ }^{a}$

\begin{tabular}{|c|c|c|c|c|c|}
\hline Phytotoxin & $\begin{array}{c}\text { Application } \\
\text { rate } \\
\left(\mu g \mathrm{~mL}^{-1}\right)\end{array}$ & $\begin{array}{l}\text { Plant height } \\
\text { (\% reduction) }\end{array}$ & $\begin{array}{c}\text { Dry wt } \\
\text { (\% reduction) }\end{array}$ & $\begin{array}{c}\text { Injury } \\
(\%)\end{array}$ & $\begin{array}{c}\text { Mortality } \\
(\%)\end{array}$ \\
\hline $\begin{array}{l}\text { Control } \\
\text { (distilled water) }\end{array}$ & 0 & 0 & 0 & 0 & 0 \\
\hline $\mathrm{FB}_{1}$ & $\begin{array}{l}6.3 \\
12.5 \\
25 \\
50\end{array}$ & $\begin{array}{c}89 \pm 16.2 \\
\text { ND } \\
\text { ND } \\
N D\end{array}$ & $\begin{array}{c}78 \pm 11.5 \\
\text { ND } \\
\text { ND } \\
\text { ND }\end{array}$ & $\begin{array}{l}100 \\
100 \\
100 \\
100\end{array}$ & $\begin{array}{c}5 \pm 1.2 \\
37 \pm 4.5 \\
92 \pm 2.0 .5 \\
100\end{array}$ \\
\hline Fusaric acid & $\begin{array}{c}6 \\
12.5 \\
25 \\
50 \\
100 \\
200 \\
400 \\
800\end{array}$ & $\begin{array}{c}6 \pm 3.3 \\
23 \pm 5.3 \\
35 \pm 5.3 \\
34 \pm 7.7 \\
34 \pm 11.2 \\
33 \pm 13.5 \\
\text { ND } \\
\text { ND }\end{array}$ & $\begin{array}{c}0 \\
0 \\
24 \pm 6.4 \\
38 \pm 7.3 \\
52 \pm 10.2 \\
55 \pm 17.2 \\
\text { ND } \\
\text { ND }\end{array}$ & $\begin{array}{c}0 \\
0 \\
80 \\
100 \\
100 \\
100 \\
100 \\
100\end{array}$ & $\begin{array}{c}0 \\
0 \\
0 \\
0 \\
0 \\
0 \\
3.5 \pm 7.2 \\
50 \pm 8.5\end{array}$ \\
\hline Moniliformin & $\begin{array}{c}6 \\
12.5 \\
25 \\
50 \\
100 \\
200 \\
400 \\
800\end{array}$ & $\begin{array}{c}0 \\
2 \pm 1.2 \\
19 \pm 3.4 \\
40 \pm 10.3 \\
43 \pm 10.3 \\
51 \pm 14.5 \\
55 \pm 18.2 \\
58 \pm 20.2\end{array}$ & $\begin{array}{c}0 \\
0 \\
5 \pm 3.3 \\
42 \pm 7.8 \\
48 \pm 7.8 \\
55 \pm 10.2 \\
60 \pm 15.2 \\
62 \pm 14.5\end{array}$ & $\begin{array}{c}0 \\
0 \\
10 \pm 3.5 \\
77 \pm 15.5 \\
100 \\
100 \\
100 \\
100\end{array}$ & $\begin{array}{l}0 \\
0 \\
0 \\
0 \\
0 \\
0 \\
0 \\
0\end{array}$ \\
\hline
\end{tabular}

a Results are the means of three replicates \pm one standard error.

b $\mathrm{ND}=$ Not determined due to mortality. 


\section{DISCUSSION}

Several F. moniliforme isolates caused substantial injury to jimsonweed plants when their fungal-rice culture extracts were applied to jimsonweed foliage. This was positively related to the production of the highly active phytotoxin FB . Damage varied depending on the amount of toxin produced by the isolate and on the production of metabolites related to $\mathrm{FB}_{1}$. These results support other findings (Abbas et al. 1991, 1992). This study also showed that fungal-rice extracts of the $F$. moniliforme isolates obtained from jimsonweed were generally more phytotoxic than those obtained from other sources, which also correlates with damage caused to jimsonweed plants by culture filtrates (Abbas et al. 1991, 1992). Extracts from the $F$. oxysporum isolate contained high levels of moniliformin and caused severe injury to jimsonweed. The phytotoxicity of moniliformin to crop and weed species is well documented (Abbas et al. 1991; Hoagland 1990b; Vesonder et al. 1992). Rice culture extracts of $F$. semitatum, A. crassa, and Cephalosporium spp. were not injurious to jimsonweed when applied without a dew period, apparently because they contained no phytotoxins. A recent study of the relationship of pathogenicity and phytotoxin production in 50 Fusarium species isolated from red clover (Trifolium pratense L.) and alfalfa (Medicago sativa L.) was also reported (Nedelnik 1992). Pathogenicity of the isolates was similar in the two plant species, but phytotoxins in fungal-culture filtrates were generally more toxic to clover. None of the phytotoxins in that study were identified.

Preparations of spores and mycelia from liquid cultures of Fusarium or Cephalosporium isolates did not infect jimsonweed, even when long dew periods (10-24 h) were used to promote propagule germination and growth on leaf surfaces. This suggests that these fungi are not pathogenic to jimsonweed, but can cause injury and mortality via the production of phytotoxic metabolites when grown on solid media such as rice. Although A. crassa did not produce any of these three phytotoxins, fungal-rice extracts of this jimsonweed pathogen did infect and cause injury and mortality to jimsonweed seedlings, but only if supplemented with a dew period of at least 10-12 $\mathrm{h}$. This dew period requirement is similar to that previously reported for this pathogen when grown on liquid media (Boyette 1986). Growth and phytotoxin production can vary with species and the choice of liquid or solid media, as reported by Alberts et al. (1993). For example, $F$. moniliforme isolate NRRLA28160 produced $460 \mu \mathrm{g} \mathrm{mL}^{-1} \mathrm{FB}$ when grown on corn meal (Vesonder etal. 1990), but produced $\leq 5 \mu \mathrm{g} \mathrm{mL}^{-1}$ on rice (Table 2).

In some cases, the injury and mortality observed in plants treated with fungalrice extracts were much lower than anticipated (based on phytotoxin content) when compared to the effects of the pure phytotoxins. Some of these isolates may have produced stereochemical isomers detected as $\mathrm{FB}_{1}$ but which are not as active as FB. Studies on the absolute and relative stereochemical configuration of $\mathrm{FB}_{1}$ indicates numerous possible isomers (Hoye et al. 1994). How the biological activity of $\mathrm{FB}_{1}$ varies with changes in stereochemistry is presently unknown. Constituents in fungal-rice extracts (starch, protein, polymers, etc.) could have prevented entry of a phytotoxin into the cuticle and plant cell walls by binding, rendering it ineffective. Such binding on foliar surfaces could prolong exposure of the phytotoxin to photo- and thermaldegradation. As an example, the F. oxysporum isolate produced high levels of moniliformin and some injury, but caused no mortality. Other studies have shown that moniliformin in ground corn and wheat exhibited a loss of $15 \%$ in samples stored at $22^{\circ} \mathrm{C}$ for $150 \mathrm{~h}$, and heating at $50^{\circ} \mathrm{C}$ for $2 \mathrm{~h}$ caused a $15 \%$ and $40 \%$ loss in corn and wheat, respectively (Scott and Lawrence 1987). Another problem with moniliformin is that its extraction and recovery are inconsistent in some instances (Scott et al. 1986), which could implicate binding and other factors. FB thermostability is somewhat greater than that of moniliformin, but some degradation occurs. FB, levels in F. moniliforme dried corn cultures were reduced by $17 \%$ after exposure to $75^{\circ} \mathrm{C}$ for $135 \mathrm{~min}$ (Dupuy et al. 1993). Greenhouse temperatures and sunlight could have 
caused substantial degradation of labile phytotoxins in our foliar-applied samples.

Although some of the secondary products of Fusarium spp. are potent phytotoxins, many of these products also exhibit mammalian toxicity. For example, $\mathrm{FB}_{1}$ is a known mammalian toxin, causing equine leukoencephalomalacia in horses and pulmonary edema in swine (Riley et al. 1993). It is, however, possible that analogs could be found with minimal mammalian toxicity and maximal herbicidal activity. This potential exists especially due to the large number of stereochemical isomers of $\mathrm{FB}$ ( Hoye et al. 1994) and because other fumonisins $\left(\mathrm{FB}_{2}, \mathrm{FB}_{3}\right.$, and $\left.\mathrm{FB}_{4}\right)$ produced by Fusarium spp. have varied phytotoxicities. Similarly, numerous analogs of moniliformin have been synthesized in an effort to obtain herbicidal products (Hoagland 1990b). Further research on the phytoxicity of fumonisin analogs is being conducted.

\section{ACKNOWLEDGEMENTS}

The moniliformin used in this study was generously provided by Dr. R.F. Vesonder, USDA-ARS, National Center for Agricultural Utilization Research, Peoria, Illinois. Fusarium species were identified by Paul E. Nelson, Fusarium Research Center, The Pennsylvania State University, Pennsylvania.

\section{REFERENCES}

Abbas, H.K., and C.D. Boyette. 1992. Phytotoxicity of fumonisin on weed and crop species. Weed Technol. $6: 548-552$.

Abbas, H.K., and C.J. Mirocha. 1985. Production of moniliformin by Fusarium moniliforme var. subglutinans isolated from wheat kernels originating in Minnesota. Microbiol. Aliment. Natr. 3 : 223-227.

Abbas, H.K., C.J. Mirocha, T. Kommedahl, R.F. Vesonder, and P. Golinski. 1989. Production of trichothecene and nontrichothecene mycotoxins by Fusarium species isolated from maize in Minnesota. Mycopathologia 108 : 55-58.

Abbas, H.K., C.D. Boyette, R.E. Hoagland, and R.F. Vesonder. 1991. Bioherbicidal potential of Fusarium moniliforme (Sheldon) and its phytotoxin, fumonisin. Weed Sci. 39 : 673-677.
Abbas, H.K., R.F. Vesonder, C.D. Boyette, R.E. Hoagland, and T. Krick. 1992. Production of fumonisins by Fusarium moniliforme cultures isolated from jimsonweed in Mississippi. J. Phytopathol. 136 : 199-203.

Alberts, J.F., W.C.A. Gelderblom, R. Vleggaar, W.F.O. Marasas, and J.P. Rheeder. 1993. Production of $\left[{ }^{14} \mathrm{C}\right]$-fumonisin $\mathrm{B}$, by Fusarium moniliforme MRC 826 in corn cultures. Appl. Environ. Microbiol. 59: 2673-2677.

Boyette, C.D. 1986. Evaluation of Alternaria crassa for biological control of jimsonweed : host range and virulence. Plant Sci. 45: 223-228.

Burmeister, H.R., and R.D. Plattner. 1987. Enniatin production by Fusarium tricinctum and its effect on germinating wheat seeds. Phytopathology 77 : 1483-1487.

Chen, J., C.J. Mirocha, W. Xie, L. Hogge, and D. Olson. 1992. Production of the mycotoxin fumonisin $B_{1}$ by Alternaria alternata f. sp. lycopersici. Appl. Environ. Microbiol. 58 : 3928-3931.

Datnoff, L.F., and J.B. Sinclair. 1988. The interaction of Fusarium oxysporum and Rhizoctonia solani in causing root rot in soybeans. Phytopathology 88 : 771-777.

Duke, S.O., H.K. Abbas, C.D. Boyette, and M. Gohbara. 1991. Microbial compounds with the potential for herbicidal use. Proc. Brighton Crop Prot. Conf.-Weeds 3b-2 : 155164.

Dupuy, J., P. Le Bars, H. Boudra, and J. Le Bars. 1993. Thermostability of fumonisin $\mathrm{B}_{1}$, a mycotoxin from Fusarium moniliforme, in corn. Appl. Environ. Microbiol. 59 : 2864-2867.

Gelderblom, W.C.A., M.K. Jaskiewicz, W.F.O. Theil, P.G. Horak, R.M. Vleggaar, and N.P.J. Kriek. 1988. Fumonisins - novel mycotoxins with cancer-promoting activity produced by Fusarium moniliforme. Appl. Environ. Microbiol. 54 : 1806-1811.

Hoagland, R.E., ed. 1990a. Microbes and microbial products as herbicides. Am. Chem. Soc. Symp. Ser. No. 439, ACS Books, Washington, DC. $347 \mathrm{pp}$.

Hoagland, R.E. 1990b. Microbes and microbial products as herbicides - an overview. Pages 1-52 in R.E. Hoagland (ed.), Microbes and microbial products as herbicides. Am. Chem. Soc. Symp. Ser. No. 439, ACS Books, Washington, DC. 
Hoagland, R.E., and C.D. Boyette. 1994. Pathogenic interactions of Alternaria crassa and phenolic metabolism in jimsonweed (Datura stramonium L.) varieties. Weed Sci. 42 : 44-49.

Hoye, T.R., J.I. Jimenez, and W.T. Shier. 1994. Relative and absolute configuration of fumonisin $\mathrm{B}_{1}$ backbone. J. Am. Chem. Soc. 116: 9409-9410.

Jones, J.P., and S.S. Woltz. 1981. Fusariumincited diseases of tomato and potato and their control. Pages 157-168 in P.E. Nelson, T.A. Toussoun, and R.J. Cook (eds.), Fusarium: diseases, biology, and taxonomy. Penn. State Univ. Press, University Park, Pennsylvania.

Kuo, M.S., and R.P. Scheffer. 1964. Evaluation of fusaric acid as a factor in development of Fusarium wilt. Phytopathology 54 : 10411044.

Labuschagne, N., J.M. Kotze, and J.F. Putterrill. 1987. Incidence of Fusarium solani and $F$. oxysporum in citrus roots and infection by F. solani. Phytophylactica $19: 315-318$.

Lukens, R.J. 1960. Conidial production from filter paper cultures of Helminthosporium vagans and Alternaria solani. Phytopathology $50: 867-868$.

Matsuo, T. 1982. Fusarium as plant pathogens. Pages 83-84 in Y. Ueno (ed.), Trichothecenes - chemical, biological, and toxicological aspects. Elsevier, Amsterdam.

Mirocha, C.J., D.G. Gilchrist, W.T. Shier, H.K. Abbas, Y. Wen, and R.F. Vesonder. 1992. AAL-toxins, fumonisins (biology and chemistry) and host-specificity concepts. Mycopathologia 117 : 47-56.

Mitich, L.W. 1989. Intriguing world of weeds - Jimsonweed. Weed Technol. $3: 208-210$.

Nedelník, J. 1992. Comparison of pathogenicity and ability to produce phytotoxins of Fusarium species isolated from red clover and alfalfa in Czecho-Slovakia. IHAR Radzików 37 : 177-180.

Nelson, P.E. 1992. Taxonomy and biology of Fusarium moniliforme. Mycopathologia 117: 29-36.

Nelson, P.E., T.A. Toussoun, and W.F.O. Marasas. 1983. Fusarium species - An illustrated manual for identification. Penn. State Univ. Press, University Park, Pennsylvania. 193 pp.
Riley, R.T., W.P. Norred, and C.W. Bacon. 1993. Fungal toxins in foods: recent concerns. Annu. Rev. Nutr. 13 : 167-189.

Scott, P.M., and G.A. Lawrence. 1987. Liquid chromatographic determination and stability of the Fusarium mycotoxin moniliformin in cereal grains. Am. Assoc. Off. Anal. Chem. $70: 850-853$.

Scott, P.M., G.A. Lawrence, and T.I. Matula. 1986. Analysis of toxins of Fusarium moniliforme. Pages 305-316 in P.S. Steyn and R. Vlegger (eds.), Mycotoxins and phycotoxins. Elsevier, Amsterdam.

Stack, R.W., and M.P. McMullen. 1985. Head blighting potential of Fusarium species associated with spring wheat heads. Can. J. Plant Pathol. 7 : 79-82.

Tanaka, T., H.K. Abbas, and S.O. Duke. 1993. Structure-dependent phytotoxicity of fumonisin and related compounds in a duckweed bioassay. Phytochemistry 33 : 779-785.

TeBeest, D.O., ed. 1991. Microbial control of weeds. Chapman and Hall, New York. $284 \mathrm{pp}$.

Timer, L.W. 1982. Host range and host colonization, temperature effects, and dispersal of Fusarium oxysporum f.sp. citri. Phytopathology 72 : 698-702.

Van Asch, M.A.J., F.H.P. Rijkenberg, and T.A. Coutinho. 1992. Phytotoxicity of fumonisin $\mathrm{B}_{1}$, moniliformin, and T-2 toxin to corn callus cultures. Phytopathology 82 : 13301332.

Vesonder, R.F., R.E. Peterson, R. Plattner, and D. Weisleder. 1990. Fumonisin $B_{1}$ isolation from corn culture, and purification by high performance liquid chromatography. Mycotoxin Res. 6 : 85-88.

Vesonder, R.F., R.E. Peterson, D.P. Labeda, T., and H.K. Abbas. 1992. Comparative phytotoxicity of fumonisins, AAL-toxin and yeast sphingolipids in Lemna minor $\mathrm{L}$. (duckweed). Arch. Environ. Contam. Toxicol. 23 : 464-467.

Windels, C.E., P.M. Burnes, and T. Kommedahl. 1988. Five-year preservation of Fusarium species in silica gel and soil. Phytopathology 78 : 107-109. 